\title{
Pengaruh Media Virtual Reality Pada Materi Pemanasan Global Terhadap Hasil Belajar Peserta Didik Kelas VII SMP Negeri 3 Palangka Raya
}

\author{
The Effect of Virtual Reality Media in Global Warming Materials Against Class \\ VII Student Learning Outcomes at SMPN 3 Palangka Raya
}

\author{
Miftahul Qori'ah ${ }^{1}$, Agus Haryono $^{2} \&$ Nuriman Wijaya ${ }^{3 *}$ \\ ${ }^{1}$ Jurusan Pendidikan MIPA/FKIP - Universitas Palangka Raya, \\ Palangka Raya - Indonesia 73111 \\ *E-mail: miftahulqoriah97@gmail.com
}

\begin{abstract}
Abstrak
Materi pemanasan global memiliki karakteristik yang sangat erat hubungannya dengan kondisi di lingkungan sekitar, memerlukan pengamatan yang lama dan prosesprosesnya tidak dapat dilihat secara langsung. Mempelajari materi pemanasan global meggunakan media virtual reality akan mempermudah proses pembelajaran karena dengan virtual reality akan menampilkan gambaran proses terjadinya pemanasan global dalam bentuk video animasi yang telah divisualkan. Penelitian ini dilakukan untuk mengetahui pengaruh media virtual reality terhadap hasil belajar peserta didik.

Penelitian ini merupakan penelitian eksperimen dengan rancangan eksperimen semu (quasi experiment). Sampel diambil dengan teknik purposive sampling pada kelas VII-8 dan VII-9 SMP Negeri 3 Palangka Raya yang masing-masing kelas berjumlah 32 orang peserta didik. Instrumen yang digunakan dalam penelitian ini yaitu soal tes pilihan ganda yang berjumlah 25 soal dan angket respon peserta didik terhadap media virtual reality. Data hasil belajar diambil dengan menggunakan soal tes yang diberikan pada saat awal pembelajaran (pretest) dan akhir pembelajaran (posttest). Data hasil belajar peserta didik kemudian dianalisis secara kuantitatif menggunakan uji Mann-Whitney.

Hasil penelitian menunjukkan bahwa perhitungan uji Mann-Whitney memperoleh hasil nilai Asymp. Sig. (2-tailed) $(0,040)<\alpha(0,05)$, maka Ho ditolak dan Ha diterima, dengan kata lain terdapat pengaruh media virtual reality terhadap hasil belajar peserta didik pada materi pemanasan global kelas VII SMP Negeri 3 Palangka Raya. Rata-rata hasil belajar peserta didik pada ranah kognitif C3, C4 dan C5 kelas eksperimen yang diajarkan menggunakan media virtual reality lebih unggul dibandingkan kelas kontrol. Hasil ini didukung juga oleh angket respon peserta didik yang menunjukkan media virtual reality berada pada kategori sangat baik. Oleh karena itu, media virtual reality pada materi pemanasan global dipandang berhasil dan berpengaruh nyata hasil belajar peserta didik.
\end{abstract}

Kata kunci: Media Virtual Reality, Pemanasan Global, Hasil Belajar

\begin{abstract}
The material of global warming has characteristics that are very closely related to conditions in the surrounding environment, requiring long observations and processes that cannot be seen directly. Studying the material of global warming using virtual reality media will simplify the learning process because virtual reality will display a
\end{abstract}


picture of the process of global warming in the form of visual videos that have been visualized. This research was conducted to determine the effect of virtual reality media on student learning outcomes.

This research is an experimental research with a quasi experiment. Samples were taken by purposive sampling technique in class VII-8 and VII-9 SMPN 3Palangka Raya, each of which consisted of 32 students. The instruments used in this study were multiple choice test questions totaling 25 questions and student responses to virtual reality media. Data on learning outcomes are taken using the test questions given at the beginning of learning (pretest) and the end of learning (posttest). Data on student learning outcomes were then analyzed quantitatively using the Mann-Whitney test.

he results showed that the Mann-Whitney test calculation obtained the Asymp. Sig. (2tailed) $(0.040)<\alpha(0.05)$, then Ho is rejected and Ha is accepted, in other words there is a significant effect of virtual reality media on the learning outcomes of students in class VII of the global warming material at SMP Negeri 3 Palangka Raya. The average learning outcomes of students in the cognitive realm of $\mathrm{C} 3, \mathrm{C} 4$ and $\mathrm{C} 5$ in the experimental class taught using virtual reality media were superior to the control class. This result is also supported by the questionnaire responses of students who show that virtual reality media is in a very good category. Therefore, virtual reality media on the subject of global warming is seen as successful and significantly influences student learning outcomes.

Keywords: Media Virtual Reality, Global Warming, Learning Outcomes 


\section{PENDAHULUAN}

Media pembelajaran adalah sejumlah alat bantu, bahan, simulasi atau program yang digunakan dalam pembelajaran untuk memperlancar keberhasilan belajar (Rusmawan, 2015). Media pembelajaran memiliki fungsi diantaranya adalah membantu mempermudah proses belajar dan meningkatkan pengalaman belajar. Media pembelajaran yang lazim digunakan yaitu media grafis, audio, transparasi, proyektor tak tembus pandang, mikrofis, film, televisi dan video.

Media pembelajaran merupakan salah satu hal penting yang ada dalam proses belajar. Penggunaan media pembelajaran di sekolah menengah pertama (SMP) saat ini masih kurang bervariasi. Berbagai kendala dalam proses pembelajaran mengharuskan guru untuk dapat memilih media pembelajaran yang sesuai dan diminati oleh peserta didik. Salah satu media pembelajaran yang menarik dan dianggap dapat mempermudah pemahaman peserta didik yaitu menggunakan media virtual reality.

Virtual reality adalah teknologi yang menciptakan lingkungan secara virtual. Teknologi virtual reality merupakan salah satu teknologi yang menjanjikan, dimana dengan media virtual reality pengguna akan disuguhkan dengan dunia maya seperti aslinya. Di Indonesia pengembangan materi sekolah dengan virtual reality hampir tidak ada, virtual reality di Indonesia masih didominasi dari pengguna gadget dengan aplikasi game (Sulistyowati dan Rahman, 2017). Selain itu, menurut Elgamal dkk. (2012) penggunaan virtual reality sebagai media belajar, media virtual reality memberikan pengaruh yang positif terhadap peningkatan hasil belajar. Berdasarkan beberapa uraian di atas, dapat disimpulkan bahwa dengan virtual reality yang menggunakan sensor Accelerometer dan Gyroscope pada media pembelajaran dapat meningkatkan hasil belajar.

Pemanasan global merupakan salah satu materi yang terdapat pada mata pelajaran IPA kelas VII SMP/MTs pada semester genap. Karakteritstik materi pemanasan global sangat erat hubungannya dengan kondisi di lingkungan sekitar, memerlukan pengamatan yang lama dan prosesprosesnya tidak dapat terlihat secara langsung. Menurut Rustaman (2011) karakteristik materi biologi memerlukan kemampuan berpikir tingkat tinggi seperti pemikiran secara kritis, logis, analitis, bahkan kadang-kadang memerlukan pemikiran kombinatorial. Media virtual reality pada materi pemanasan global akan dapat mempermudah proses pembelajaran karena dengan virtual reality akan memperpendek durasi pembelajaran dan mendapatkan gambaran nyata proses terjadinya pemanasan global yang telah divisualkan. Media virtual reality diharapkan dapat berdampak positif terhadap peningkatan hasil belajar peserta didik pada materi pemanasan global.

\section{METODE}

Penelitian ini merupakan penelitian eksperimen dengan rancangan eksperimen semu (quasi experiment) yang dilaksanakan pada dua kelas, yaitu pada kelas eksperimen dan kelas kontrol. Sampel diambil dengan teknik purposive sampling, dimana sampel peserta didik yang dijadikan eksperimen pada kelas VII-8 dan kontrol pada kelas VII-9. Jumlah peserta didik masing-masing perlakuan yaitu masing-masing 32 peserta didik. 
Instrumen dalam penelitian ini yaitu soal pretest dan posttest pilihan ganda sebanyak 25 butir soal, RPP, LKPD dan angket respon peserta didik. Soal pretest dan posttest sebelum digunakan pada penelitian terlebih dahulu divalidasi dengan menggunakan aplikasi Anates versi 4.0.9. RPP dibuat dua kali pertemuan dengan sub bab materi efek rumah kaca dan pemanasan global pada kelas eksperimen dan kontrol. LKPD diberikan pada saat peserta didik melaksanakan diskusi dalam kelompok. Angket respon peserta didik dibuat dengan dua jawaban pernyataan yaitu ya dan tidak dan diberikan kepada peserta didik kelas eksperimen setelah pembelajaran selesai.

Teknik analisis data dilakukan dengan dua cara yaitu uji prasyarat dan uji hipotesis. Uji prasyarat analisis yang dilakukan yaitu uji normalitas dan uji homogenitas. Uji normalitas yang telah dilakukan menunjukkan bahwa data berdistribusi tidak normal. Karena data berdistribusi tidak normal, maka diuji dengan menggunakan uji hipotesis Mann-Whitney yang dihitung menggunakan SPSS Versi 18.

\section{HASIL}

Hasil pretest dan posttest peserta didik dalam penelitian ini menunjukkan bahwa ada perbedaan yang signifikan antara kelas ekperimen dan kelas kontrol. Rata-rata pretest kedua kelas tersebut menunjukkan hasil yang tidak terlalu jauh berbeda. Hal tersebut menunjukkan bahwa hasil pretest menunjukkan kemampuan awal peserta didik sebelum diberi pelakuan. Rata-rata posttest menunjukkan bahwa kelas eksperimen lebih unggul $(75,63)$ dibandingkan dengan kelas kontrol $(70,13)$. Rata hasil belajar peserta didik kedua kelas disajikan pada gambar 1.

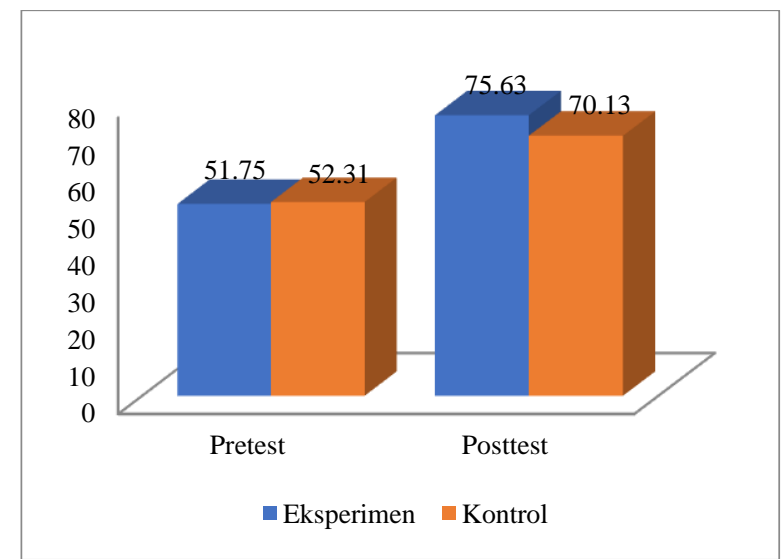

Gambar 1. Rata-Rata Hasil Belajar Kelas Eksperimen dan Kelas Kontrol

Hasil belajar peserta didik pada ranah kognitifnya pada kelas kontrol menunjukkan kelas ekperimen lebih unggul dibandingkan dengan kelas kontrol. Deskripsi hasil belajar ranah kognitif disajikan pada gambar 2. 


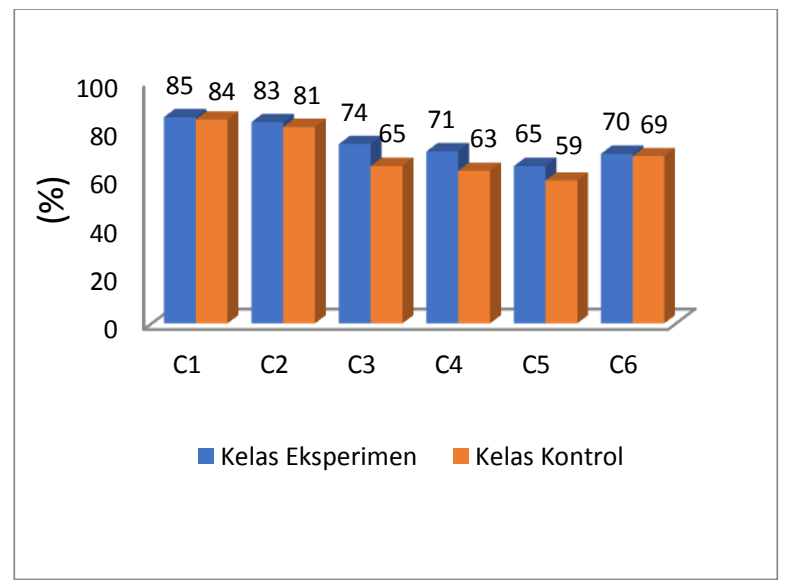

Gambar 3. Presentase Ranah Kognitif C1-C6

Gambar 3 menunjukkan bahwa hasil belajar peserta didik untuk jenjang kognitif kelas kontrol dan kelas ekperimen berbeda. Presentase belajar untuk ranah kognitif yang memiliki selisih presentase tertinggi yaitu pada jenjang C3, C4 dan C5. Hal ini menunjukkan bahwa kelas yang diajarkan dengan media virtual reality lebih unggul dalam hasil belajar kognitifnya.

Data hasil pengamatan berdistribusi tidak normal, kemudian data diuji hipotesis dengan uji non parametrik. Hasil perhitungan analisis uji hipotesis Mann-Whitney juga menunjukkan bahwa ada pengaruh penggunaan media pembelajaran virtual reality pada materi pemanasan global dengan nilai signifikansi 0,040 . Hal ini menunjukkan bahwa terdapat pengaruh yang signifikan media pembelajaran virtual reality pada materi pemanasan global terhadap hasil belajar kognitif peserta didik kelas VII di SMP Negeri 3 Palangka Raya.

Hasil penelitian yang dilakukan menunjukkan bahwa media virtual reality berpengaruh secara signifikan terhadap hasil belajar kognitif peserta didik. Hasil penelitian ini juga diperkuat dengan hasil penelitian yang hampir serupa yang diteliti oleh Arifin (2018) yang menunjukkan adanya peningkatan hasil belajar peserta didik pada materi sistem tata surya kelas VII setelah menggunakan media pembelajaran virtual reality pada kelas eksperimen.

Hasil belajar pada jenjang kognitif C3, C4 dan C5 terlihat perbedaan hasil belajar kelas eksperimen yang menggunakan media virtual reality lebih unggul dibandingkan dengan kelas kontrol yang menggunakan powerpoint. Kemampuan kognitif kelas eksperimen tingkat C3 memiliki selisih 9\%, C4 $8 \%$, dan C5 6\%. Hal ini juga sesuai dengan penelitian yang dilakukan oleh Ulfa (2012) yang menunjukkan bahwa pembelajaran dengan media virtual reality berpengaruh terhadap pemahaman dan kemampuan peserta didik dengan kemampuan menganalisis.

Media virtual reality mendapatkan respon yang sangat baik dari peserta didik. Peserta didik terlihat antusias saat menggunakan media virtual reality pada saat pembelajaran pemanasan global. Hasil presentase respon peserta didik disajikan dalam tabel 1. 
Tabel 1. Hasil Angket Respon Peserta Didik

\begin{tabular}{|c|c|c|c|c|}
\hline \multirow{2}{*}{ No. } & \multirow{2}{*}{ Pernyataan } & \multicolumn{2}{|c|}{ Jawaban } & \multirow{2}{*}{ Presentase } \\
\hline & & Ya & Tidak & \\
\hline 1 & $\begin{array}{l}\text { Media virtual reality pada pembelajaran materi } \\
\text { pemanasan global lebih menarik dibandingkan } \\
\text { dengan media pembelajaran yang biasa digunakan. }\end{array}$ & 32 & 0 & $100 \%$ \\
\hline 2 & $\begin{array}{l}\text { Tampilan video animasi materi pemanasan global } \\
\text { dengan virtual reality yang dapat dilihat dengan } \\
360^{\circ} \text { lebih mudah dipahami. }\end{array}$ & 28 & 4 & $88 \%$ \\
\hline 3 & $\begin{array}{l}\text { Ukuran gambar yang ditampilkan pada video } \\
\text { virtual reality dapat terlihat dengan jelas. }\end{array}$ & 23 & 9 & $72 \%$ \\
\hline 4 & $\begin{array}{l}\text { Suara yang terdapat pada virtual reality terdengar } \\
\text { jelas. }\end{array}$ & 32 & 0 & $100 \%$ \\
\hline 5 & $\begin{array}{l}\text { Kualitas video yang disajikan dalam virtual reality } \\
\text { kurang menarik. }\end{array}$ & 9 & 23 & $72 \%$ \\
\hline 6 & $\begin{array}{l}\text { Media virtual reality pada materi pemanasan } \\
\text { global mampu mengarahkan anda untuk belajar } \\
\text { mandiri. }\end{array}$ & 25 & 7 & $78 \%$ \\
\hline 7 & $\begin{array}{l}\text { Anda merasa kesulitan dalam menggunakan virtual } \\
\text { reality box (VR box) dalam pembelajaran. }\end{array}$ & 4 & 28 & $88 \%$ \\
\hline 8 & $\begin{array}{l}\text { Anda merasa pusing setelah memakai media } \\
\text { virtual reality. }\end{array}$ & 6 & 26 & $81 \%$ \\
\hline 9 & $\begin{array}{l}\text { Anda setuju jika media virtual reality digunakan } \\
\text { lagi oleh guru dalam materi biologi lainnya. }\end{array}$ & 27 & 5 & $84 \%$ \\
\hline 10 & $\begin{array}{l}\text { Media virtual reality baik jika diterapkan di } \\
\text { sekolah. }\end{array}$ & 32 & 0 & $100 \%$ \\
\hline & Rata-rata & & & $86 \%$ \\
\hline
\end{tabular}

Media pembelajaran virtual reality dapat membuat peserta didik lebih mudah mengingat dan mengamati konsep yang diajarkan. Hal ini juga didukung oleh hasil angket respon peserta didik pada indikator tampilan video animasi materi pemanasan global dengan virtual reality yang dapat dilihat dengan $360^{\circ}$ lebih mudah dipahami yang memperoleh presentase sebeser $88 \%$ dan memperoleh rata-rata presentase keseluruhan $86 \%$. Hal ini juga sesuai dengan pernyataan Levie \& Levie (dalam Arsyad, 2014) bahwa belajar melalui stimulus gambar akan membuahkan hasil belajar yang lebih baik untuk tugas-tugas seperti mengingat, mengenali, mengingat kembali, dan menghubungkan fakta dan konsep. Hasil angket respon peserta didik juga menunjukkan bahwa media virtual reality cocok digunakan dalam pembelajaran dengan kategori sangat baik.

\section{SIMPULAN}

Berdasarkan hasil penelitian yang telah dilakukan, dapat disimpulkan bahwa terdapat pengaruh signifikan media virtual reality terhadap hasil belajar peserta didik pada materi pemanasan global kelas VII SMP Negeri 3 Palangka Raya. Hal ini terlihat dari uji hipotesis dengan menggunakan Mann-Whitney terhadap data posttest, dimana nilai Asymp. Sig. (2-tailed) $(0,040)<\alpha(0,05)$. Rata-rata hasil belajar peserta didik pada ranah kognitif yang menggunakan media pembelajaran virtual reality kelas eksperimen lebih unggul dibandingkan kelas kontrol terutama pada ranah kognitif $\mathrm{C} 3$, C4 dan C5 kelas eksperimen $(74 \%, 71 \%, 65 \%)$ lebih unggul dari kelas kontrol $(65 \%, 63 \%, 59 \%)$. Hasil ini didukung juga oleh angket respon 
peserta didik yang menunjukkan bahwa pembelajaran menggunakan media virtual reality berada pada kategori sangat baik.

\section{REFERENSI}

Arifin, I. 2018. Pengaruh Penggunaan aplikasi Virtual Reality Terhadap Hasil Belajar Peserta didik Pada Materi Sistem Tata Surya. Skripsi. Lampung: Universitas Lampung.

Arsyad, A. 2014. Media Pembelajaran. Jakarta: Rajawali Pers.

Elgamal, A. F., Eldesoky, M., Abdelmohsen, N. \& Hussien, M. 2012. The Effectiveness of a proposed system Based on desktop virtual reality to promote the basic concepts of Computer security. International Journal Computer Technology \& Applications. Vol.3.

Rusmawan, W. 2015. Urgensi Media Pembelajaran dalam KBM. Diunduh pada tanggal 3 Januari 2019, dari http://www.lpmpjabar.go.id/index.php/artikel/208-urgensimediapembelajaran dalam-kbm.

Rustaman, N.Y. 2011. Pendidikan dan Penelitian Sains Dalam Mengembangkan Keterampilan Berpikir Tingkat Tinggi Untuk Pembangunan Karakter. Makalah Seminar Nasional VIII. P.Biologi, FKIP UNS, Surakarta.

Sulistyowati dan Andi, R. 2017. Pemanfaatan Teknologi 3d Virtual Reality Pada Pembelajaran Matematika Tingkat Sekolah Dasar. Jurnal Ilmiah NERO.

Ulfa, R. 2012. Pengaruh Multimedia Virtual Reality Terhadap Pemahaman Dan Kemampuan Analisis Siswa Kelas VIII Smp Negeri 1 Ajibarang Dalam Mempelajari Konsep IPA Biologi. Bachelor thesis. Purwokerto: Universitas Muhammadiyah Purwokerto.

\section{UCAPAN TERIMA KASIH}

Penulis mengucapkan terimakasih kepada bapak Prof. Dr. Agus Haryono, M.Si. selaku dosen pembimbing I dan bapak Drs. Nuriman Wijaya, M.Pd. selaku dosen pembimbing II yang telah rela meluangkan waktu dan dengan ikhlas memberikan bimbingan kepada penulis. Terimakasih kepada temanteman serta semua pihak yang telah membantu dalam penyelesaian artikel ini. 